\title{
INNOVATION-INTERNATIONALISATION LOCI IN MARKET TRANSITION OF INFORMATION AND TELECOMUNICATIONS FIRMS
}

\author{
Maja Bašić ${ }^{2}$ \\ UDC / UDK: 330.342.14/.15:005.591.6:339.94:654(497.5) \\ JEL classification / JEL klasifikacija: P2, L96, O3 \\ DOI: https://doi.org/10.22598/pi-be/2020.14.1.27 \\ Original scientific paper / Izvorni znanstveni rad \\ Received / Primljeno: April 1, 2020 / 1. travnja 2020. \\ Accepted for publishing / Prihvaćeno za tisak: May 20, 2020 / 20. svibnja \\ 2020 .
}

\section{Summary}

The purpose of this study is to analyse differences in a small open transitional economy's loci on innovation and internationalisation pace. Specifically, the effect of absorptive capacity, product and service innovation, and institutional support on internationalisation pace differences between firms founded in the command and capitalist market systems. Geographical setting of this study is the Republic of Croatia, which underwent a transition from a command to a capitalist market system in the early 1990s. Its information and telecommunications firms were pillars of innovation. The survey on Croatian information and telecommunications' firms' innovation and internationalisation was done between March and May 2014. This paper analysed 82 single firm responses based on firms': internationalisation pace, amount of product and service innovation, absorptive capacity and institutional support in finding international markets. Results show that greater service innovation and smaller institutional support lead to faster internationalisation for all firms in the sample. When distinguishing between firms founded in the command system ("incumbents") and those founded in the capitalist system ("young firms"), neither the amount of absorptive capacity, their product nor service innovation statistically significantly predict incumbents' internationalisation pace. Conversely, young firms' internationalisation pace was: (a) positively influenced by service innovation and absorptive capacity, and (b) negatively by product innovation and institutional support. Hence, absorptive capacity and service innovation are more important for internationalisation pace of firms founded in the capitalist system, which is consistent with the globally integrated growth of the information and telecommunications industry. This paper further

\footnotetext{
${ }^{2}$ Maja Bašić, Ph.D., University of Zagreb, Faculty of Economics and Business, Croatia, Email: mbasic1@net.efzg.hr
} 
discusses theoretical and practical implications of the identified findings with respect to the small open transitional economy.

Keywords: Internationalisation pace, Transitional economy, Absorptive capacity, Product and service innovation, Information and ttelecommunications industry.

\section{INTRODUCTION}

Development of a successful national economy that promotes high living standards for its citizens requires successful and effective supply- and demand-side policies. $20^{\text {th }}$ century countries in command and capitalist economic systems competed to achieve economic growth. Command economies of the mid- $20^{\text {th }}$ century effectively allocated national resources until 1970s' technological revolution, when a high rate of innovation of capitalist economies challenged the lagging competitive position of command economies (Berliner, 1978). The results imply towards possible inefficiencies in innovation system (Högselius, 2017).

Central and Eastern European sectoral differences surpass national and regional determinants of innovation systems that are transitioning from command to capitalist economy (Radosevic, 1999). Central and Eastern European economies' sectoral innovation performance was heavily influenced by foreign firms (Radosevic, 1999) implying towards its contemporary global integration, based on which successful technology transfer is depended on the availability of high-skilled labour possessing technical knowledge and innovative skills (von Hirschhausen \& Bitzer, 2000). Although the pattern or pace of internationalisation cannot be generalised (Riviere and Bass, 2019), Central and Eastern European economies were expected to obtain patterns similar to those of the developed European counterparts, which should have advanced country's competitive advantage.

This paper fills the gap in internationalisation-innovation loci research by analysing differences in a small open transitional economy's loci on innovation and internationalisation pace. Namely, it tries to answer the research question: "Are there differences in innovation-internationalisation pace between the two different market systems?". It focused on the geographical setting of the Republic of Croatia, which is a small open transitional economy, that transitioned from the command system of the former SFR Yugoslavia towards a capitalist market system after the Independence War in the first half of the 1990s. Although Croatia's 'crony variance of capitalism' inhibited its innovation culture more than explanations based on the socio-cultural heritage of socialism (Švarc, 2017), information and telecommunications industry was, and remained, one of the Croatia's most important infrastructure and innovation industries. Therefore, this paper studies the telecommunications industry in Croatia, as a sector specific, innovative and globally integrated industry encompassing economic and geopolitical importance (e.g., Hugill, 1999) during its transition from a command towards a capitalist market system. Namely, the share of telecommunications industry in Croatia's GDP was $4.59 \%$ in 2008, with its investment accounting for $15.49 \%$ of 
revenue; and in 2017 ICT goods imports comprised $5.02 \%$ of total goods imports, ICT exports totalled $2.51 \%$ of total goods exports, ICT services exports were $5,0 \%$ of total services exports (World Bank, 2019). Furthermore, in order to answer the research question on the differences in innovation-internationalisation pace loci in two different market systems, this paper takes a closer look into Croatia's information and telecommunications firms' product and service innovation, absorptive capacity and government help in finding international market niche assist with respect to internationalisation pace. Information and telecommunications firms' internationalisation pace's is significant because its speed enables them to become global players (e.g., Telefónica) or its internationalisation slowness diminishes even their domestic market share (e.g., BT) (Clifton et al., 2011). In order to differentiate between the two market systems in Croatia, a distinction is made between firms founded before 1990s, in the command market system, and after the 1995 in the capitalist market system, to determine whether differences in absorptive capacity, product or service innovation and institutional support exist between the two systems.

\section{LITERATURE REVIEW}

Transition between command or centrally planned economic systems demands changes in institutions as well as economic performance (Kekic, 1996). Based on the systems of innovation perspective (Nelson, 1993; Lundvall, 1992; Edquist; 1997), Radosevic (1999) argues that long term growth is accompanied by different systems of innovation; namely, different compositions and strengths or network actors. In the command market systems actors encompassed ministries or R\&D institutes, and in the capitalist market system actors are privately owned businesses. With respect to demandin the command market system, demand lags behind a demand in the capitalist market system preventing the innovation of products based on consumer preferences and lead user theory, i.e., inhibiting innovation potential (Dunning, 1988; Kornai, 2010). As firms' knowledge influences internationalisation (Sedoglavich, 2012), Kornai (2010) shows that the penetration of modern technology is much slower in the post-command market systems as opposed to capitalist market systems, indicating lower absorptive capacity of the economies arising from the command system.

Absorptive capacity is a firm's ability to acquire and assimilate, transform and exploit knowledge available in its environment by engaging it to produce products and services of higher added value (Cohen and Levinthal, 1990; Zahra and George, 2002; Huang and Rice, 2009; Todorova and Durisin, 2007; Casillas et al., 2009; Arte, 2017). Absorptive capacity is important for technological catch up, especially for firms from transitional economies. Highly skilled and knowledge-intensive labour supply enables transformation of external innovation into competitive products and services. Howell (2020) notes that higher absorptive capacity is related to higher productivity in areas of denser production networks, in which productivity gains occur due to externalities caused by technological-related knowledge spillovers, which are more significant in 
more intensive market transitions, thereby allowing accelerated market entry (Langseth et al., 2016; Falahat et al., 2018).

Although faster internationalisation usually implies exports or investments in neighbouring countries with similar environments with fewer transaction costs (Hutzschenreuter et al., 2016; Schubert et al., 2018), absorptive capacity of firms from transition markets enables firms to internationalise beyond neighbouring countries (Panibratov and Klishevich, 2020). Moreover, learning-by-exporting is beneficial for low absorptive capacity countries, i.e., low absorptive capacity countries seem to benefit more from importing and exporting as their scope of learning is higher (Filippetti et al., 2017), while in highly competitive industries, such as those from the capitalist systems, effects of absorptive capacity on knowledge search are diminished (Wang and Guo, 2020). Both internationalisation and absorptive capacities are path dependant (Casillas and Moreno-Menendez, 2014). Absorptive capacity depends on the R\&D investment.

García-Quevedo et al. (2014) found that previous R\&D experience is a fundamental determinant for mature and young firms. Pellegrino et al. (2012) define it as a firm with less than 8 years of activity. They also show that in-house R\&D is linked to the propensity to introduce product innovation both in incumbent firms and young firms, whereby higher innovation results in young firms' connection to external sources rather than those in incumbents, where inhouse R\&D is important. Additionally, a young innovative company is usually defined as a firm younger than 6 years old, with fewer than 250 employees and with more than $15 \%$ of its revenue invested in research and development activities (Audretsch et al., 2014). Audretsch et al. (2014) stress that initial innovation capacity and cooperation in R\&D projects influences young firms' probability of becoming an innovative firm, i.e., implying faster growth. Almus (2000) examined the young firms in the technology and non-technology intensive sectors in West Germany in the period 1898-1994 finding no significant differences between young technology intensive firms and non-technology intensive ones in all periods examined. Furthermore, Mitchell and Singh (1992) show that incumbents delay the investment into research and development of new technologies when new technological subfields emerge due to uncertainty and the fear of product cannibalisation.

Hence, for the purpose of this study, differentiation is made between firms founded during Croatia's command market system, i.e., firms founded prior 1995, so called industry incumbents, and those founded in the capitalist market system, i.e., after 1995. 1995 is used as a cut off year because of the Independence War Croatia underwent in the period 1991-1995. Based on the above stated, the following hypothesis proposes:

Hypothesis 1: There exist differences in absorptive capacity between incumbents and young firms that leads to differences in their internationalization pace.

Hypothesis 1a: Incumbents' lower absorptive capacity leads to faster internationalisation.

Hypothesis 1b: Young firms' greater absorptive capacity leads to faster internationalisation. 
For young, technology-based firms with limited domestic market size with changing institutional pattern internationalisation implies depiction of international market niches, that finds a lead user and allows a profit growth from returns on R\&D investment (Oviatt and McDougall, 2005; Ronkko et al., 2013; Stayton and Mangematin, 2016; Riviere and Bass, 2019; Patel et al., 2014; Lin and Si, 2019).

SMEs in Central and Eastern Europe internationalisation pattern are entwined in networks that assist their knowledge creation and exchange, and are crucial for firms' successful internationalisation (Stoian et al., 2016). Liberalisation of trade and integration into the European Union's market resulted in internationalisation of firms from transitional markets of Central and Eastern Europe's former command economies. This internationalisation occurred mostly in downstream value chain activities (Cieslik et al., 2016), where firms had expectations to move towards the upstream of value chains with a gradual increase in their innovation capabilities.

Differentiation between incumbents and young firms' internationalisation pace provides mixed results. Ronkko et al. (2013) found that the effect of innovation on internationalisation is only significant for young firms at the beginning of their operations (Ronkko et al., 2013). Oliveira et al. (2018) found that sector-specific young firms are not more innovative than incumbents, while a research on 8163 Indian listed firms over 18 years found that younger firms founded after 1991 are more likely to pursue aggressive internationalisation (Kumar et al., 2020). A study of young innovative Flemish firms found that they grow significantly faster than other firms (Czarnitzki and Delanote, 2013). Puig et al. (2018) depict better internationalisation success of slow internationalisers in the manufacturing industry. Finally, Fernhaber et al. (2007) contradict the conventional notion that firms internationalise in their mature stage as young firms tend to internationalise earlier when the industry is in its growth stage due to its resource abundance.

In the information and telecommunications industry, product developments are nowadays mainly in the mature stage of life cycle and outsourced to China, while service innovation is in its a growth stage with multiple application advancements. If differentiation is made between product and service innovation, it can be proposed that in cases of young firms' service innovation will positively and product innovation will negatively affect internationalisation. Furthermore, similarly as with R\&D investment, incumbents tend to delay innovation until market and technical uncertainties subside (Mitchell and Singh, 1992). Hence, second hypothesis proposes:

Hypothesis 2: Differences between incumbents and young firms' product and service innovation lead to differences in internationalisation pace.

Hypothesis 2a: Incumbents with lower levels of product and service innovation experience faster internationalisation.

Hypothesis 2b: Young firms with lower levels of product innovation and higher levels of service innovation experience faster internationalisation. 
Germany serves as good example of differences between a command (previously the East Germany) and capitalist (previously the West Germany) market system in which the East Germany underwent a transition after the German unification in 1990. Keck (1993) describes the innovation-internationalisation differences in Germany after the World War II. Institutional innovation differences ranged from financial support for purchasing foreign equipment to the government-financed system of education and research. While the West Germany's export performance in the 1988 was comparable to the export performance of the USA and Japan in the same periods, the East Germany's was not. Moreover, German innovation-internationalisation link was led by a business sector that provided direction both of research and export performance.

The Republic of Croatia has undergone a transition from command to a capitalist market system in the early 1990s, it experiences challenges because of its inadequate institutional framework. The importance of institutional support originates in the fact that innovation is a dynamic and global process, which requires organisational and product adaptation to new markets that are complimented by both private and public entities (Guinet and Meissner, 2012).

Internationalisation process of Polish firms in command system, during the transition period as well as after the transition period ended, was affected by the changing institutional conditions such that firms founded during or after a transition process tended to internationalise faster and in greater depth than incumbents (Ciszewska-Mlinaric et al., 2018). Additionally, Szerb and Trumbull (2018) examined the institutional support to transition countries' firms, finding a weak institutional support for entrepreneurs in post-Soviet Russia. Conversely, data from 3803 privately owned enterprises in China had shown that privately owned firms whose owners bear a socialist (command) imprint act more readily on policy-induced opportunities to make profit, but their attention towards government policies is crucial (Dai et al., 2018). However, in regions characterised by higher institutional development, neither the attention towards government policies nor socialist imprint were as important.

Institutional policy oriented towards technology and knowledge transfer and import substitution of the $19^{\text {th }}$ century established Germany as a leader and top world exporter in pharmaceutical and chemical industries, and which was replaced by World War II challenges attributed to diversification between the East and the West banking system that supported the restructuring of industries, industrial relations that limited trade union and industry conflict, as well as social and labour market policies that aided German development in reversing the negative trend caused by the World War II. However, majority of the West German exports were concentrated in Europe (about $70 \%$ ), and were protected against non-European products. In 1987 German firms did not rely on government expenditure as a source of $R \& D$, but $63 \%$ of $R \& D$ was provided by a business sector, while $97 \%$ of funds provided by a business sector were spent by a business sector, out of which $7 \%$ is for other businesses and $1 \%$ for cooperative research. Furthermore, West Germany both received foreign funds for domestic R\&D and spent domestic funds for foreign R\&D (Keck, 1993). This implies 
towards the importance of absorptive capacity but also towards the importance of investment that is guided by the free market forces during that period.

Firms with lack of knowledge of a geographical area will enter a foreign market through a network rather than as a single entity (Chipp et al., 2019). Current research provides mixed results whether local, foreign or a balance of the two institutional networks fosters higher internationalisation pace (Patel et al., 2014). Likewise, mixed results depict the shape of the relationship between innovation and internationalisation pace (Pucci et al., 2016). Although generally greater innovation increases firm growth (Almus and Nerlinger, 1999) and internationalisation pace, factors such as internationalisation potential and market uncertainty could negatively influence the decision to innovate and, consequently internationalise (Audretsch et al., 2014). Calvino et al. (2016) found that young firms are systematically more exposed to the policy environment and national framework conditions than incumbents. If the level of the industry's global integration is high, it will lead to faster internationalisation for young firms (Fernhaber et al., 2007). High global integration of information and telecommunications industry, especially in terms of young firms and service innovation, could lead to the negative effect of institutional support for young firms and free market forces outperform institutional support factors. Hence, the third hypothesis proposes:

Hypothesis 3: Differences in institutional support in finding international markets between incumbents and young firms leads to different internationalisation pace.

Hypothesis 3a: Greater institutional support in finding international markets leads to faster internationalisation for incumbents.

Hypothesis 3b: Lower institutional support in finding international markets leads to faster internationalisation for young firms.

Figure 1 shows the proposed model of research hypotheses. 


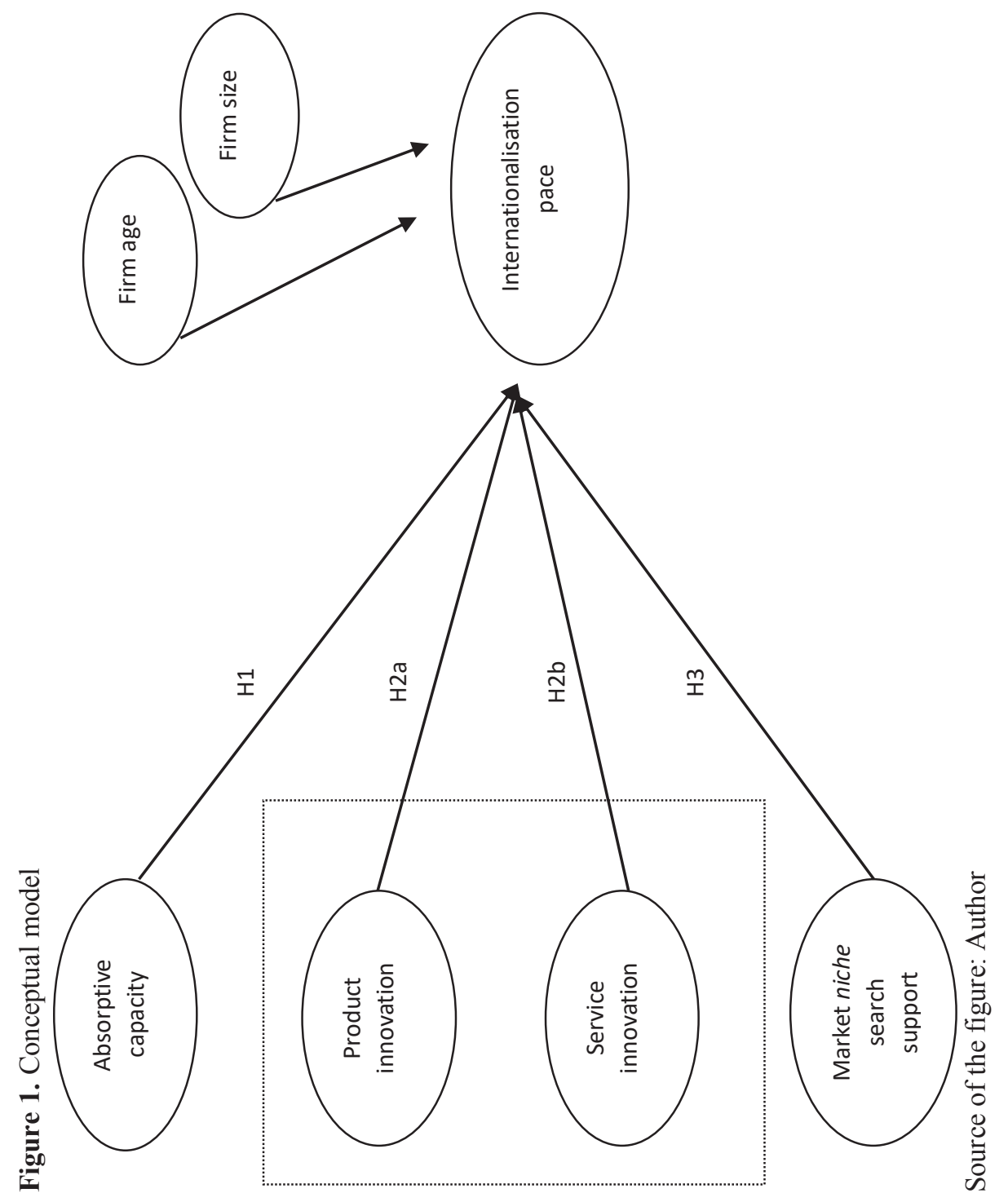




\section{RESEARCH METHOD}

\subsection{Data source and sample}

The institutional transformations caused convergence of telecommunications on one side and information technologies on the other side. They are a result of a disruption in the information and telecommunications industry caused by telecommunications firms investing in research and development in information and communications technologies, such as Internet applications (Palmberg and Martikainen., 2006) or government policies (Etzkowitz and Leydesdorff, 2000). Information and telecommunications industry comprises both manufacturing and service firms (e.g., Xing et al., 2011). This research also included both manufacturing and service firms. Firms in the information and telecommunications industry are often both manufacturing and service firms, which was one of the reasons why telecommunications industry was chosen as a research sample, i.e., the ability that by analysing it valid conclusions can be drawn by distinguishing between and incorporating both, product and service innovation.

The Registry of business entities of the Republic and the Orbis database identifies 347 business entities in Croatia's telecommunications industry. Data was gathered via online questionnaire survey done between April and May 2014 for the purpose of the Ph.D. thesis on a sample of firms from the Republic of Croatia's telecommunications industry. The online questionnaire survey was sent via email to the $\mathrm{CEO}, \mathrm{CFO}$ and COOs of identified firms. In several instances more than one response per firm was obtained. In that case, the answers were averaged to represent an average response to be obtained across a firm. After data cleaning of 128 gathered responses, 82 valid responses were tested in this analysis.

\subsection{Variables and measures}

\subsubsection{Dependent variable}

Internationalisation pace is a dependent variable. It measures how fast firms internationalise after their foundation, i.e., how many years it takes firms to internationalise after their foundation. Internationalisation pace was calculated as a difference between internationalisation and foundation year. Hierarchical and K-means cluster analysis has shown the existence of two clusters: Firms that internationalised within 5 years of their founding are fast internationalisers ( $37 \mathrm{firms}$ ) and those that internationalised after 5 years were labelled as slow internationalisers (45 firms) (Oviatt and McDougall, 1994).

\subsubsection{Independent variables}

Absorptive capacity is a firm's ability to acquire and assimilate the knowledge, and transform and exploit it through higher value added of its products and services (Cohen and Levinthal, 1990; Zahra and George, 2002). In this paper absorptive capacity is measured by the amount of knowledge a firm possesses and uses. Originally, absorptive capacity was measured by the firm's R\&D expenditure (Cohen and Levinthal, 1990). Firms have the ability to transfer knowledge developed in its environment and use it by 
qualified personnel to obtain new products and services (Spithoven et al., 2010). Hence, possession of knowledge is a prerequisite for innovation (Tseng et al., 2011). This paper, therefore, measures absorptive capacity as a measure of acquisition of knowledge (Arbussa and Coenders, 2007) by asking respondents to evaluate the amount of licences their firm possess in the past 4 years. The answers were measured on a Likert scale from 1- none to 7 - a lot.

Similarly, product and service innovation were evaluated based on the amount of product and service innovation a firm produced in the 4 years preceding the survey (Terziovski, 2010). Product and service innovation was defined as new or significantly altered products or services. Product and service innovation were measured with two items representing: product innovation and service innovation. Both items were ordinal and measured on a Likert scale from 1 - none to 7 - a lot.

Institutional support in finding international markets was based on respondents' perception of how much do government agencies' support firms in identifying international markets niches (Busenitz et al., 2000). It was measured on a Likert scale from 1 - not at all to 7 - very much.

\subsubsection{Control variables}

In order to remedy the problem of sampling and non-response bias, two control variables are inputed in the model: firm age and firm size. Consistent with Ronkko et al. (2013), firm age influences the pace of firm growth and internationalisation. Therefore, firm age was used as a control variable. Furthermore, firm size influences the pace of internationalisation as larger firms have significantly more resources to invest in market research, but less flexibility in adopting to foreign markets as opposed to smaller firms. The effects of firm size and firm age on the internationalisation pace. Firm size was measured with the number of firm employees (Choi and Contractor, 2016). The answers were recorded on Likert scale: (1) 1 employee, (2) 2- 5 employees, (3) 6-10 employees, (4) 11-50 employees, (5) 51-150 employees, (6) 151-250 employees, and (7) more than 251 employees. As this might not be enough to remedy the sampling and non-response bias (Cheung et al., 2017) by following an example of Bonnichsen and Olsen (2016), the problem tried to be mitigated by grouping the data on firm age: incumbents and young firms, whose dates of incorporation were checked on the firms' websites and the public registry of firms.

\subsubsection{Tested model}

The following equation describes the tested model:

$$
y=\beta 1 x 1+\beta 2 x 2+\beta 3 x 3+\beta 4 x 4+\beta 5 x 5+\beta 6 x 6+\varepsilon
$$

where $\mathrm{y}$ is the internationalisation pace, $\beta_{1 \ldots 6}$ are coefficients of the independent variables, $x_{1 . .6}$ are independent variables, $x_{1}-$ firm size, $x_{2}-$ firm age, $x_{3}$-institutional support, $x_{4}$ - absorptive capacity, $x_{5}$ - product innovation and $x_{6}$ - service innovation, and $\varepsilon$ is the error term. 


\section{FINDINGS}

The empirical analysis was based on 82 single firm responses $(23,6 \%$ response rate). 47 firms (57,32\% of the sample) in the sample have 50 employees or less; 18 firms (21,95\% of the sample) are medium-sized firms employing between 50 and 250 workers; and 17 firms (20,73\% of the sample) are large firms with more than 250 employees. The Independence War between 1991 and 1995 marked the Republic of Croatia's transition from a command towards a capitalist market system. 19 respondent firms were founded in 1995 or prior the transition to a market-based system took place. For the purpose of this analysis and in line with structure of the information and telecommunications industry, those firms are named incumbents. 63 firms in the analysis were founded after 1995 , i.e., in the capitalist market system. For the purpose of this analysis we name them young firms. Table 1. shows descriptive statistics and correlations between variables in the model.

Table 1. Descriptive statistics and correlation

\begin{tabular}{|c|c|c|c|c|c|c|c|c|c|c|}
\hline & Variable & Mean & S.D. & 1 & 2 & 3 & 4 & 5 & 6 & 7 \\
\hline 1. & Internationalisation pace & 0.55 & 0.50 & 1 & & & & & & \\
\hline 2. & Firm size & 2.32 & 1.13 & 0.05 & 1 & & & & & \\
\hline 3. & Firm age & 4.71 & 1.44 & $0.21^{*}$ & 0.17 & 1 & & & & \\
\hline 4. & Institutional support & 1.53 & 0.87 & $-0.43 * * *$ & -0.16 & $0.02 * *$ & 1 & & & \\
\hline 5. & Absorptive capacity & 2.70 & 1.95 & $0.22 * *$ & -0.03 & -0.02 & 0.10 & 1 & & \\
\hline 6. & Product innovation & 4.00 & 1.94 & -0.07 & 0.18 & -0.00 & 0.06 & 0.15 & 1 & \\
\hline 7. & Service innovation & 4.45 & 1.77 & $0.31^{* * *}$ & -0.09 & 0.10 & $-0.20 *$ & $0.26 * *$ & 0.14 & 1 \\
\hline
\end{tabular}

Note: $\mathrm{N}=82$. S.D. $=$ standard deviation. Two-tailed test. Pearson correlation reported. All variables were standardised.

$* * * \mathrm{p}<0.01, * * \mathrm{p}<0.05, * \mathrm{p}<0.10$

Source: Author's calculations.

Positive significant correlation exists between: (1) internationalisation pace and absorptive capacity, (2) internationalisation pace and service innovation, and (3) service innovation and absorptive capacity. On the other hand, significant negative correlation exists between internationalisation pace and institutional support.

Binomial logistic regression was used to test the hypotheses due to the existing two samples of firms: fast and slow internationalisers. The results of the performed binomial logistic regression are given in Table 2 . 


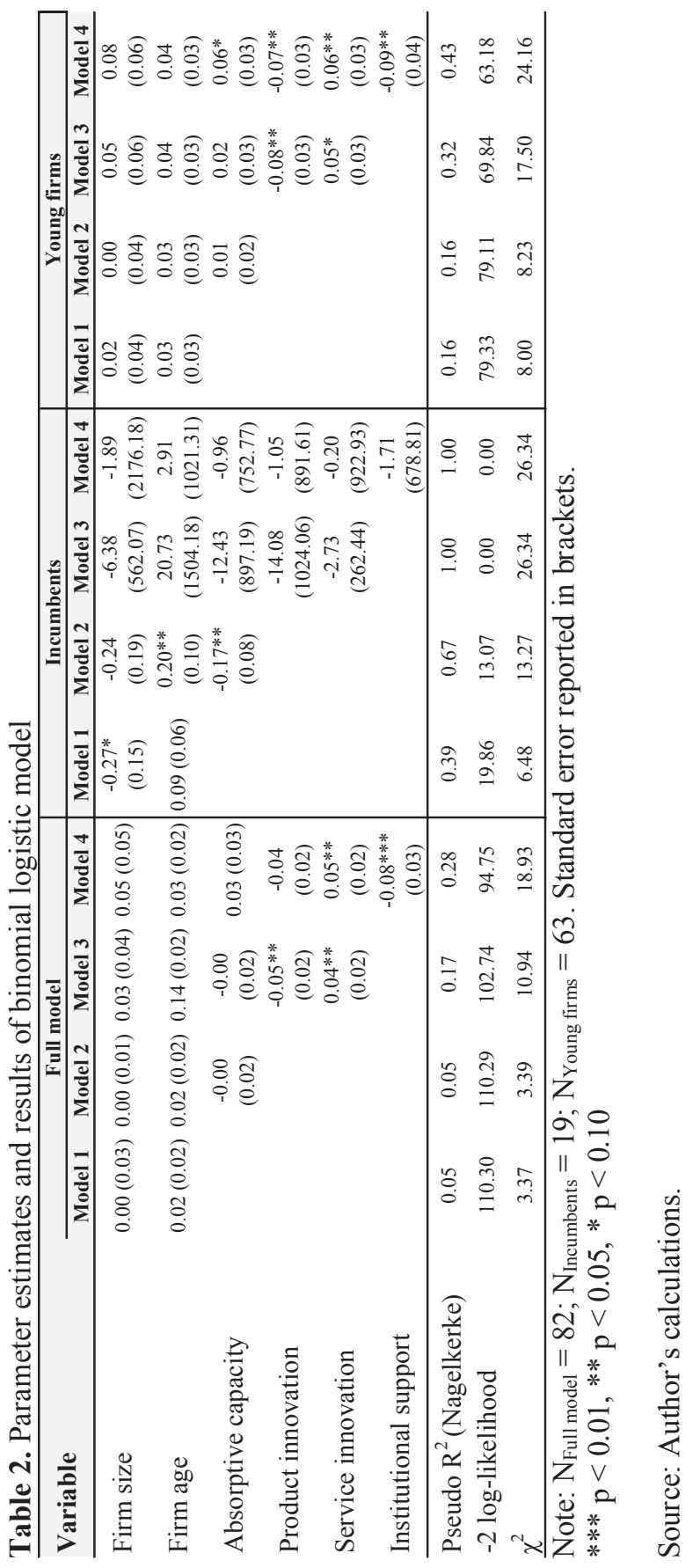


Binomial logistic regression tested four models incorporating: (1) control variables, and (2) absorptive capacity, and (3) product and service innovation, and (4) perceived institutional support. Furthermore, each of the four models was tested for samples of (a) firms founded earlier than 1995 in the command system, i.e., incumbents, and (b) firms founded after 1995 in the capitalist market system, i.e., young firms. 1995 was used as a cut off year due to the Independence War that finished in 1995 in Croatia, and also because of the data available and obtained from the online questionnaire.

In a full model, absorptive capacity does not have a significant effect. Product innovation has a negative significant effect only when institutional support is not in the model. When institutional support is in the model, product innovation still has a negative effect on internationalisation pace, while service innovation has a positive significant effect. It can be assumed that part of the negative effect of product innovation is now attributed to the institutional support variable.

In a sample of incumbent firms, the only significant effect on internationalisation pace is noted in the negative effect of absorptive capacity on internationalisation pace. Hence, greater absorptive capacity implies slower internationalisation.

A significant negative effect of product innovation, a positive effect of service innovation, and a negative effect of institutional support on internationalisation pace is noted in a sample of young firms. Absorptive capacity has a negative effect in a sample of young firms, which is significant only at a $10 \%$ significance level.

Summary of the tested hypotheses is given in Table 3.

Table 3. Summary of hypotheses' tests

\begin{tabular}{|c|c|c|c|c|}
\hline & & Full model & Incumbents & $\begin{array}{l}\text { Young } \\
\text { firms }\end{array}$ \\
\hline H1 & $\begin{array}{l}\text { Absorptive capacity } \rightarrow \\
\text { Internationalisation pace }\end{array}$ & Partially supported & $\begin{array}{l}\text { Partially } \\
\text { supported }\end{array}$ & $\begin{array}{l}\text { Partially } \\
\text { supported }\end{array}$ \\
\hline $\mathrm{H} 2$ & $\begin{array}{l}\text { Product innovation } \rightarrow \\
\text { Internationalisation pace }\end{array}$ & - & $\begin{array}{l}\text { Partially } \\
\text { supported }\end{array}$ & Supported \\
\hline $\mathrm{H} 2$ & $\begin{array}{l}\text { Service innovation } \rightarrow \\
\text { Internationalisation pace }\end{array}$ & Partially supported & $\begin{array}{l}\text { Partially } \\
\text { supported }\end{array}$ & Supported \\
\hline H3 & $\begin{array}{l}\text { Institutional support } \rightarrow \\
\text { Internationalisation pace }\end{array}$ & - & - & Supported \\
\hline
\end{tabular}

Source: Author

Absorptive capacity influences internationalisation pace of incumbents negatively and internationalisation pace of young firms positively (at a 10\% significance level). Product innovation negatively influences international pace. The negative effect of product innovation on internationalisation pace is stronger in a sample of younger firms. Service innovation has a strong positive effect on internationalisation pace of young firms. Institutional support has a significant negative effect on internationalisation pace, especially in a sample of young firms. Figure 2. illustrates the final full model of incumbents and young firms. 


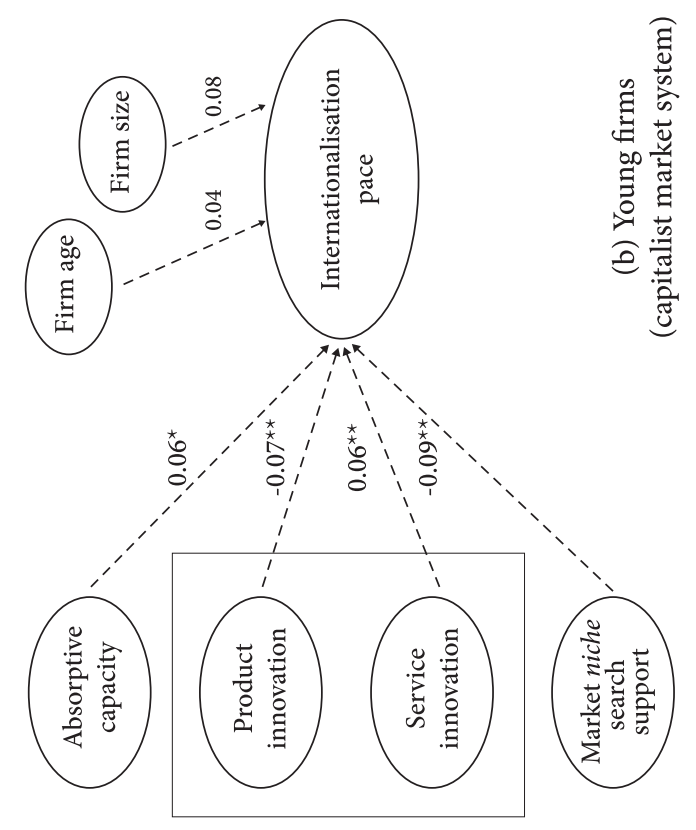

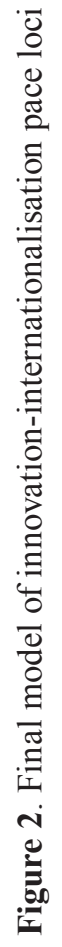

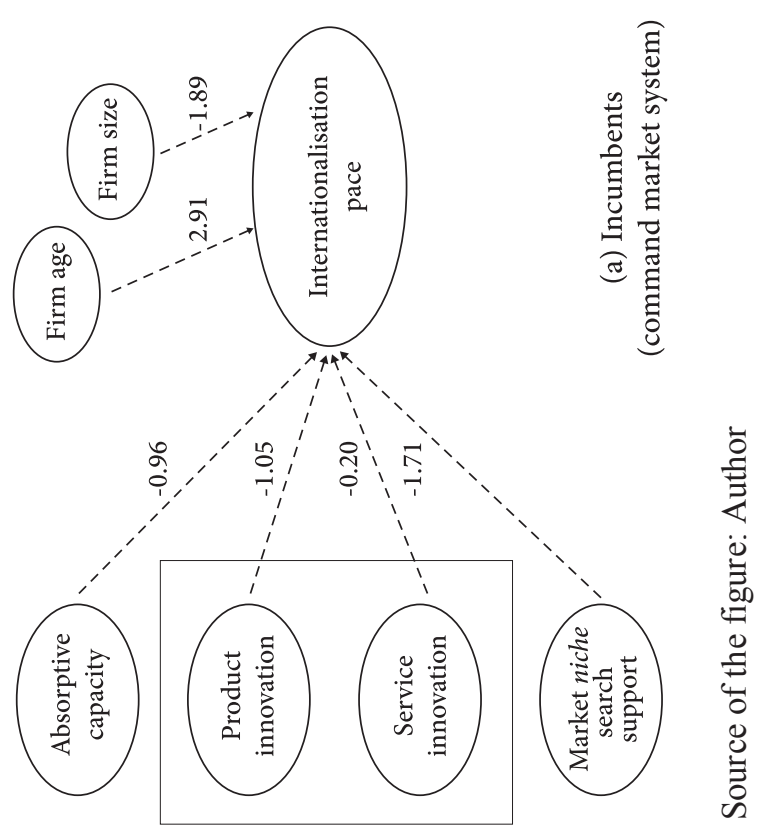


The final model is divided into: (a) a model that depicts the relationship of absorptive capacity, innovation and institutional support with internationalisation pace for incumbents, i.e., firms founded in the command market system, and (b) a model that depicts the named relationships for young firms, i.e., firms founded in the capitalist market system. Firms founded in the command market system have a negative and insignificant relationship with internationalisation pace implying that none of the variables significantly impacted the pace of internationalisation. This relationship is illustrated with broken arrows. On the other hand, firms founded in the capitalist market system have a significant relationship with internationalisation pace for almost all variables, which is market with full line arrows. Product innovation and institutional support slowed down the internationalisation pace for firms founded in the capitalist market system, while absorptive capacity and service innovation increased the pace of internationalisation.

\section{CONCLUSION}

This paper attempted to answer the research question: "Are there differences in innovation-internationalisation pace between the two different market systems?". Thereby it aimed to fill in the gap in internationalisation-innovation loci research by comparing firms founded in the command market system, founded prior 1995 and named incumbents for the purpose of this study, and firms founded in the capitalist market system, founded after 1995 and named young firms for the purpose of this study. It analysed differences in a small open transitional economy's loci on innovation and internationalisation pace by examining Croatia's information and telecommunications firms' product and service innovation, absorptive capacity and government help in finding international market niche assist with respect to internationalisation pace. Information and telecommunications firms' internationalisation pace's enables globally integrated industry firms to either become global players or erode their domestic market share (Clifton et al., 2011).

In terms of the first hypothesis, this study aligns with the Mitchell and Singh's (1992) work as nonsignificant relationship between absorptive capacity and internationalisation pace of incumbents was found. Their reasoning that incumbents delay the investment into research and development of new technologies when new technological subfields emerge due to uncertainty and the fear of product cannibalisation could provide a reasonable explanation. In terms of young firms, i.e., those founded in the capitalist market system, this study finds that absorptive capacity positively affects internationalisation pace. A possible explanation is provided by Audretsch et al. (2014) who state that initial innovation capacity and cooperation in R\&D projects influences young firms' probability of becoming an innovative firm, i.e., implying their faster growth.

In terms of the second hypothesis, this study finds that there are differences between incumbents and young firms' product and service innovation that lead to differences in internationalisation pace. As the information and telecommunications 
industry is globally integrated and in the mature stage of the life cycle in terms of products, it is consistent with Mitchell and Singh (1992) who show that incumbents, i.e., firms founded in the command market system, tend to delay innovation due to market and technical uncertainties, both in terms of product and service innovation. On the other hand, young firms, i.e., those founded in the capitalist market system, have service innovation that positively and product innovation that negatively affect internationalisation pace. This is consistent with Fernhaber et al. (2007) as the service innovation part of the information and telecommunications industry is currently undergoing growth and in Croatia, experiencing resource abundance with young ICT firms.

The results of the third hypothesis are aligned with Fernhaber et al. (2007) who found that in the globally integrated industry such as the information and telecommunications industry, faster internationalisation is experienced by young firms and service innovation, as free market forces in the current capitalist market system outperform institutional support factors of the prior slow command system. Also, Audretsch et al.'s (2014) explanation which states that internationalisation potential and market uncertainty could negatively influence the decision to innovate and internationalise, and Keck's (1993) observation of slower pace of internationalisation of East (command system) compared to West (capitalist system) Germany prior to German unification, imply the possible negative effect of institutional support on the internationalisation pace of firms founded in the capitalist system.

This research has several limitations. It is a cross-sectional study and it would be interesting to study the information and telecommunications industry longitudinally, especially after the period of Croatia's joining the European Union Another limitation lies in the shortcoming of the research sample and the data. Future studies should take care to take the secondary financial data to both increase the sample size and remedy the sample bias problems.

\section{REFERENCES}

1. Almus, M. (2000) Testing "Gibrat's Law" for Young Firms - Empirical Results for West Germany. Small Business Economics, 15, pp. 1-12. https://doi.org/10.1023/A:1026512005921

2. Almus, M., \& Nerlinger, E. A. (1999). Growth of new technology-based firms: which factors matter?. Small Business Economics, 13(2), pp. 141-154. https://doi.org/10.1023/A:1008138709724

3. Arbussa, A. and Coenders, G. (2007). Innovation activities, use of appropriation instruments and absorptive capacity: Evidence from Spanish firms, Research Policy, 36 (10), pp. 1545-1558.

4. Arte, P. (2017). Role of experience and knowledge in early internationalisation of Indian new ventures A comparative case study. International Journal of Entrepreneurial Behavior \& Research, 23 (6), pp. 850-865. 
5. Audretsch, D. B., Segarra, A., \& Teruel, M. (2014). Why don't all young firms invest in R\&D?. Small Business Economics, 43(4), pp. 751-766. https://doi.org/10.1007/s11187-014-9561-9

6. Berliner, J. S. (1978). The innovation decision in Soviet industry. MIT Press Books, 1 (1), Number 0262520524, August.

7. Bonnichsen, O. and Olsen, S. B. (2016). Correcting for non-response bias in contingent valuation surveys concerning environmental non-market goods: an empirical investigation using an online panel. Journal of Environmental Planning $\begin{array}{llll}\text { and } \quad \text { Management, } & 59 & \text { (2), }\end{array}$ https://doi.org/10.1080/09640568.2015.1008626

8. Busenitz, L. W., Gomez, C. and Spencer, J. W. (2000). Country institutional profiles: Unlocking entrepreneurial phenomena. Academy of Management Journal, 43(5), pp. 994-1003. https://doi.org/10.5465/1556423

9. Calvino, F., Criscuolo, C. and Menon, C. (2016). No Country for Young Firms?: Start-up Dynamics and National Policies. OECD Science, Technology and Industry Policy Papers, 29, OECD Publishing, Paris, https://doi.org/10.1787/5jm22p40c8mw-en

10. Casillas, J. C. and Moreno-Menendez, A. M. (2014). Speed of the internationalization process: The role of diversity and depth in experiential learning, Journal of International Business Studies, 45 (1), pp. 85-101.

11. Casillas, J. C., Moreno, A. M., Acedo, F. J., Gallego and M.A., Ramos, E. (2009). An integrative model of the role of knowledge in the internationalization process, Journal of World Business, 44(3), pp. 311-322.

12. Cheung, K.L., ten Klooster, P.M., Smit, C., de Vries, H. and Pieterse, M.E. (2017). The impact of non-response bias due to sampling in public health studies: A comparison of voluntary versus mandatory recruitment in a Dutch national survey on adolescent health. BMC Public Health, 17 (276), 10 pages. doi: 10.1186/s12889017-4189-8

13. Chipp, K., Wocke, A., Strandberg, C. and Chiba, M. (2019). Overcoming African institutional voids: market entry with networks, European Business Review, 31 (3), pp. 304-316.

14. Choi, J. and Contractor, F. J. (2016). Choosing an appropriate alliance governance mode: The role of institutional, cultural and geographical distance in international research \& development (R\&D) collaborations. Journal of International Business Studies, 47(2), pp. 210-232. https://doi.org/10.1057/jibs.2015.28

15. Cieślik, E., Biegańska, J., \& Środa-Murawska, S. (2016). The intensification of foreign trade in post-socialist countries and their role in global value chains. Acta Oeconomica, 66(3), 465-487. https://doi.org/10.1556/032.2016.66.3.5

16. Ciszewska-Mlinaric, M., Obloj, K. and Wasowska, A. (2018). Internationalisation choices of Polish firms during the post-socialism transition period: The role of institutional conditions at firm's foundation. Business History, 60 (4), pp. 562-600.

17. Clifton, J., Comín, F., \& Díaz-Fuentes, D. (2011). From national monopoly to multinational corporation: How regulation shaped the road towards 
telecommunications internationalisation. Business History, 53(5), pp. 761-781. https://doi.org/10.1080/00076791.2011.599588

18. Cohen, W. M. and Levinthal, D. A. (1990). Absorptive capacity: A new perspective on learning and innovation, Administrative Science Quarterly, 35 (1), pp. 128-152.

19. Czarnitzki, D., \& Delanote, J. (2013). Young innovative companies: the new highgrowth firms?. Industrial and Corporate Change, 22(5), pp. 1315-1340. https://doi.org/10.1093/icc/dts039

20. Dai, W., Liu, Y., Liao, M., Lin, Q. (2018). How does entrepreneurs' socialist imprinting shape their opportunity selection in transition economies? Evidence from China's privately owned enterprises. International Entrepreneurship and Management Journal, 14, 823-856. https://doi.org/10.1007/s11365-017-0485-0

21. Dunning, J. H. (1988). The eclectic paradigm of international production: A restatement and some possible extensions, Journal of International Business Studies, 19 (1), pp. 1-31.

22. Edquist, C. (ed.) (1997). Systems of Innovation: Technologies, Institutions and Organisations, London: Pinter Publisher.

23. Etzkowitz, H. and and Leydesdorff, L. (2000). The dynamics of innovation: from National Systems and "Mode 2" to a Triple Helix of university-industry-government relations. Research Policy, 29 (2), pp. 109-123. https://doi.org/10.1016/S00487333(99)00055-4

24. Falahat, M., Thurasamy, R. and Senik, Z. C. (2018). Strategic Capabilities for Rapid Internationalization: Conceptualization and Measurement. Collection of papers from Innovation management and education excellence through vision 2020, I -XI, Milan, Italy, April 2018, 31st International Business Information Management Association Conference, International Business Information Management Association, Milan, pp. 6947-6958.

25. Fernhaber, S., McDougall, P.P. and Oviatt, B.M. (2007). Exploring the Role of Industry Structure in New Venture Internationalization. Entrepreneurship Theory and Practice, 31 (4), pp. 517-542. https://doi.org/10.1111/j.1540-6520.2007.00186.x

26. Filippetti, A., Frenz, M. and Ietto-Gillies, G. (2017). The impact of internationalization on innovation at countries' level: the role of absorptive capacity. Cambridge Journal of Economics, 41(2), pp. 413-439. https://doi.org/10.1093/cje/bew032

27. García-Quevedo, J., Pellegrino, G. and Vivarelli, M. (2014). R\&D drivers and age: Are young firms different? Research Policy, 43 (9), pp. 1544-1556. https://doi.org/10.1016/j.respol.2014.04.003

28. Guinet, J. and Meissner, D. (2012). Open Innovation: Implications for Corporate Strategies, Government Policy and International R\&D Spillovers, Foresight and Sti Governance, 6 (1), pp. 26-37.

29. Högselius, P. (2017). The dynamics of Innovation in post-Communist Countries: opportunities and Challenges. In Industries and Markets in Central and Eastern Europe (pp. 85-104). Routledge. 
30. Howell, A. (2020). Relatedness economies, absorptive capacity, and economic catchup: firm-level evidence from China. Industrial and Corporate Change, 29(2), pp. 557-575. https://doi.org/10.1093/icc/dtz050

31. Huang, F. and Rice, J. (2009). The role of absorptive capacity in facilitating "open innovation" outcomes: A study of Australian SMEs in the manufacturing sector, International Journal of Innovation Management, 13 (2), pp. 201-220.

32. Hugill, P. J. (1999). Global communications since 1844: Geopolitics and technology. JHU Press.

33. Hutzschenreuter, T., Kleindienst, I., Guenther, C. and Hammes, M. (2016). Speed of Internationalization of New Business Units: The Impact of Direct and Indirect Learning, Management International Review, 56 (6), pp. 849-878.

34. Keck, O. (1993). The national system for technical innovation in Germany. National innovation systems: A comparative analysis, pp. 115-157.

35. Kekic, L. (1996). Assessing and Measuring Progress in the Transition, Economies in Transition: Regional Overview, EIU Country Forecast, 2nd quarter 1996, London: Economist Intelligence Unit.

36. Kornai, J. (2010). Innovation and dynamism: Interaction between systems and technical progress 1. Economics of transition, 18(4), pp. 629-670.

37. Kumar, V., Singh, D., Purkayastha, A., Popli, M., \& Gaur, A. (2020). Springboard internationalization by emerging market firms: Speed of first cross-border acquisition. Journal of International Business Studies, 51(2), 172-193. https://doi.org/10.1057/s41267-019-00266-0

38. Langseth, H., O'Dwyer, M. and Arpa, C. (2016). Forces influencing the speed of internationalisation An exploratory Norwegian and Irish study, Journal of Small Business and Enterprise Development, 23 (1), pp. 122-148.

39. Lin, S. and Si, S. (2019). The influence of exploration and exploitation on born globals' speed of internationalization. Management Decision, 57 (1), pp. 193-210.

40. Lundvall, Bengt-Åke (ed.) (1992). National Systems of Innovation - Towards a Theory of Innovation and Interactive Learning, London: Pinter Publishers.

41. Mitchell, W. and Singh, K. (1992). Incumbents' use of pre-entry alliances before expansion into new technical subfields of an industry. Journal of Economic Behavior \& Organization, 18 (3), pp. 347-372. https://doi.org/10.1016/0167-2681(92)900154

42. Nelson, R. R. (ed.) (1993). National innovation systems: a comparative analysis. Oxford University Press on Demand.

43. Oliveira, A. P., Meneses, R. and Moutinho, N. (2018). Are INV so different? Collection of papers from Strategica: Challenging The Status Quo in Management and Economics, in book series: Strategica, Busharest, Romania, October 2018, 6th International Academic Conference on Strategica - Challenging the Status Quo in Management and Economics, Bucharest, pp. 304-318.

44. Oviatt, B.M. and McDougall, P.P. (1994). Toward a theory of international new ventures, Journal of International Business Studies, 25 (1), pp. 45-64. 
45. Oviatt, B.M. and McDougall, P.P. (2005). Defining international entrepreneurship and modeling the speed of internationalization, Entrepreneurship Theory and Practice, 29 (5), pp. 537-554.

46. Palmberg, C. and Martikainen, O. (2006). Diversification in response to ICT convergence-indigenous capabilities versus R\&D alliances of the Finnish telecom industry. Info, 8(4), pp. 67-84. https://doi.org/10.1108/14636690610676559

47. Panibratov, A. and Klishevich, D. (2020). Dynamic capabilities during the internationalization of MNCs from post-socialist emerging markets. Multinational Business Review. https://doi.org/10.1108/MBR-06-2019-0052

48. Patel, P. C., Fernhaber, S. A., McDougall-Covin, P. P. and van der Have, R. (2014). Beating competitors to international markets: The value of geographically balanced networks for innovation. Strategic Management Journal, 35 (5), pp. 691-711.

49. Pellegrino, G., Piva, M. and Vivarelli, M. (2012). Young firms and innovation: A microeconometric analysis. Structural Change and Economic Dynamics, 23(4), pp. 329-340. https://doi.org/10.1016/j.strueco.2011.10.003

50. Pucci, T., Casprini, E., Zanni, L. and Sinha, K. (2016). When Speed Counts, Open Innovation Matters. Collection of papers from Innovation, Entrepreneurship and Digital Ecosystems, Warsaw, Poland, September 2016, 9th Annual Conference of the EuroMed Academy of Business, Warsaw, pp. 1515-1530.

51. Puig, F., Gonzalez-Loureiro, M. and Ghauri, P. N. (2018). Running faster and jumping higher? Survival and growth in international manufacturing new ventures. International Small Business Journal: Researching Entrepreneurship, 36 (7), pp. 829-850. https://doi.org/10.1177/0266242618777792

52. Radosevic, S. (1999). Transformation of science and technology systems into systems of innovation in central and eastern Europe: the emerging patterns and determinants. Structural Change and Economic Dynamics, 10(3-4), pp. 277-320. https://doi.org/10.1016/S0954-349X(99)00016-8

53. Riviere, M. and Bass, A. E. (2019). How dimensions of internationalization shape the MNE's renewal capability: Multidimensional and multilevel considerations, Long Range Planning, 52(4), 101862, available at: https://doi.org/10.1016/j.lrp.2018.12.002 (accessed 15 September 2019).

54. Ronkko, M., Ojala, A. and Tyrvainen, P. (2013). Innovation as a Driver of Internationalization in the Software Industry. Collection of papers from International Conference on Research and Innovation in Information Systems, Kuala Lumpur, Malaysia, November 2013, 3rd International Conference on Research and Innovation in Information Systems (ICRIIS) 2013, Kuala Lumpur, pp. 49-54.

55. Schubert, T., Baier, E. and Rammer, C. (2018). Firm capabilities, technological dynamism and the internationalisation of innovation: A behavioural approach, Journal of International Business Studies, 49 (1), pp. 70-95.

56. Sedoglavich, V. (2012). Technological imperatives in the internationalization process: Results from a qualitative investigation of high-tech SMEs. Management Research Review, 35(5), pp. 441-459. 
57. Spithoven, A., Clarysse, B. and Knockaert, M. (2010). Building absorptive capacity to organise inbound open innovation in traditional industries, Technovation, 30 (2), pp. 130-141.

58. Stayton, J. and Mangematin, V. (2016). Startup time, innovation and organizational emergence: A study of USA-based international technology ventures, Journal of International Entrepreneurship, 14(3), pp. 373-409.

59. Stoian, M. C., Rialp, A., Rialp, J., \& Jarvis, R. (2016). Internationalisation of Central and Eastern European small firms. Journal of Small Business and Enterprise Development, 23 (1), 105-121. https://doi.org/10.1108/JSBED-10-2013-0159

60. Švarc, J. (2017). A socio-political approach to exploring the innovation culture in post-socialist countries: the case of Croatia. Post-Communist Economies, 29(3), pp. 359-374.

61. Szerb, L., \& Trumbull, W. N. (2018). Entrepreneurship development in Russia: Is Russia a normal country? An empirical analysis. Journal of Small Business and Enterprise Development, 25 (6), 902-929. https://doi.org/10.1108/JSBED-01-20180033

62. Terziovski, M. (2010). Innovation practice and its performance implications in small and medium enterprises (SMEs) in the manufacturing sector: a resource-based view. Strategic Management Journal, 31(8), pp. 892-902. https://doi.org/10.1002/smj.841

63. Todorova, G., and Durisin, B. (2007). Absorptive capacity: Valuing a Reconceptualization, The Academy of Management Review, 32 (3), pp. 774-786.

64. Tseng, C., Chang Pai, D. and Hung, C. (2011). Knowledge absorptive capacity and innovation performance in KIBS, Journal of Knowledge Management, 15(6), pp. 971-983.

65. von Hirschhausen, C. and Bitzer, J. (Eds.). (2000). The globalization of industry and innovation in Eastern Europe: from post-socialist restructuring to international competitiveness. Edward Elgar Publishing.

66. Wang, Y. and Guo, B. (2020). Managing external knowledge search: the multiple and contingent roles of absorptive capacity. Technology Analysis \& Strategic Management, 32 (1), pp. 29-43. https://doi.org/10.1080/09537325.2019.1632821.

67. World Bank (2019). World Development Indicators, available at: https://data.worldbank.org/country/croatia (accessed 21 October 2019).

68. Xing, W., Ye, X. and Kui, L. (2011). Measuring convergence of China's ICT industry: An input-output analysis. Telecommunications Policy, 35 (4), pp. 301-313. https://doi.org/10.1016/j.telpol.2011.02.003

69. Zahra, S. A. and George, G. (2002). Absorptive capacity: A review, reconceptualization, and extension, Academy of Management Review, 27(2), pp. 185203. 


\title{
MEĐUODNOS INOVACIJA I INTERNACIONALIZACIJE U TRŽIŠNOJ TRANZICIJI INFORMACIJSKO-TELEKOMUNIKACIJIH PODUZEĆA
}

\author{
Maja Bašić
}

\begin{abstract}
Sažetak
Svrha ove studije bila je analiza razlika između inovacija $i$ tempa internacionalizacije u maloj otvorenoj ekonomiji u tranziciji. Specifično, u radu se promatrao utjecaj apsorpcijskog kapaciteta, proizvodnih $i$ uslužnih inovacija $i$ institucionalne potpore na razlike u tempu internacionalizacije između poduzeća osnovanih u socijalističkom i kapitalističkom tržišnom sustavu. Studija se geografski bazirala na teritoriju Republike Hrvatske, koja je prošla tranziciju od socijalističkog ka kapitalističkom tržišnom sustavu ranih 1990.-ih godina. Razvoj informacijskotelekomunikacijskih poduzeća omogućavao je daljnje inovacije ostalih sektora. Upitnik $o$ inovacijama $i$ internacionalizaciji hrvatskih informacijsko-telekomunikacijskim poduzeća proveden je između ožujka i svibnja 2014. godine. Studija je analizirala 82 odgovora poduzeća o: njihovom tempu internacionalizacije, količini proizvodnih $i$ uslužnih inovacija, apsorpcijskom kapacitetu i institucionalnoj potpori u pronalasku međunarodnih tržišta. Rezultati su pokazali kako viša razina uslužnih inovacija i manja razina institucionalne potpore vode bržem tempu internacionalizacije za sva poduzeća $u$ uzorku. Uvođenje razlike između poduzeća nastalih u socijalističkom sustavu (tzv. „postojeća poduzeća“) $i$ onih nastalih u kapitalističkom sustavu (tzv. „mlada poduzeća") pokazalo je kako niti količina apsorpcijskog kapaciteta, proizvodnih ni uslužnih inovacija nisu statistički signifikantno predvidjela tempo internacionalizacije postojećih poduzeća (poduzeća nastalih u socijalističkom tržišnom sustavu). Nasuprot tome, na tempo internacionalizacije mladih poduzeća: (a) pozitivno je utjecala razina uslužnih inovacija $i$ apsorpcijskog kapaciteta, $i$ (b) negativno razina proizvodnih inovacija $i$ institucionalne potpore. Zaključuje se kako su apsorpcijski kapacitet $i$ uslužne inovacije važniji za tempo internacionalizacije poduzeća osnovanih u kapitalističkom sustavu (tzv. „mladih poduzeća“), a što je konzistentno sa sveobuhvatnim globalnim rastom i razvojem informacijsko-telekomunikacije industrije. $U$ radu se također raspravlja o teorijskim $i$ praktičnim implikacijama rezultata istraživanja u odnosu na malu otvorenu ekonomiju u tranziciji.
\end{abstract}

Ključne riječi: tempo internacionalizacije, ekonomija u tranziciji, apsorpcijski kapacitet, proizvodne i uslužne inovacije, informacijsko-telekomunikacijska industrija. 